\title{
MENGOLAH DATA VIDEO ANALOG MENJADI VIDEO DIGITAL SEDERHANA
}

\author{
Nick Soedarso \\ Jurusan Desain Komunikasi Visual, Fakultas Komunikasi dan Multimedia, \\ Bina Nusantara Universiy, Jln. K.H. Syahdan No. 9, Kemanggisan Jakarta Barat \\ nsoedarso@binus.edu
}

\begin{abstract}
Nowadays, editing technology has entered the digital age. Technology will demonstrate the evidence of processing analog to digital data has become simpler since editing technology has been integrated in the society in all aspects. Understanding the technique of processing analog to digital data is important in producing a video. To utilize this technology, the introduction of equipments is fundamental to understand the features. The next phase is the capturing process that supports the preparation in editing process from scene to scene; therefore, it will become a watchable video.
\end{abstract}

Keywords: technology, editing, analog, digital, video

\begin{abstract}
ABSTRAK
Saat ini teknologi editing sudah mulai masuk ke era digital. Teknologi ini dapat mempermudah proses pengolahan data analog ke digital karena teknologi editing sudah menjadi satu dengan keseharian dari masyarakat perkotaan dalam berbagai aspek. Pengenalan teknologi untuk mengolah sebuah data analog menjadi digital sangat penting dalam memproduksi sebuah video.Untuk memulai pemanfaatan teknologi ini, pengenalan peralatan merupakan dasar penting untuk memahami fungsi masing-masing peralatan. Tahapan berikutnya adalah proses capturing yang kemudian akan mendukung persiapan di dalam proses penyuntingan adegan demi adegan, sehingga dapat menjadi sebuah video yang bisa dinikmati.
\end{abstract}

Kata kunci: teknologi, editing, analog, digital, video 


\section{PENDAHULUAN}

Era digital sudah masuk dan siap untuk menggantikan era analog yang selama ini kita kenal. Meskipun peralatan yang digunakan sudah menggunakan tehnologi yang baru, namun proses kerjanya relatif sama. Perkembangan video analog ke digital semakin memudahkan untuk menghasilkan sebuah video yang kreatif dan sangat menarik untuk di pelajari karena semakin berkembangnya dari tehnologi saat ini.

Pada saat ini, era digital juga sudah merambah ke dalam kehidupan sehari hari seperti, $L C D$ TV, DVD Player, home theater sampai dengan perangkat Blue Ray yang merupakan teknologi terakhir untuk menikmati tayangan film dengan resolusi tinggi. Dalam perkembangannya, dimana pasaran untuk televisi menggunakan layar datar yang menggantikan TV konvensional yang menggunakan tabung.LCD (Liquid Chrystal Display) yang sudah mempunyai resolusi yang tinggi serta teknologi yang terbaru menggunakan layar LED (Light Emitting Diode) yang lebih hemat $40 \%$ pemakaian listrik dibanding dengan layar $L C D$.

Maraknya perkembangan editing video ini juga mendorong banyaknya sekolah, universitas dan lembaga pelatihan formal dan layanan pelatihan secara online yang menarik minat banyak orang untuk belajar dalam dunia editing. Selain lembaga lembaga pelatihan formal, banyak orang yang bisa belajar secara otodidak dan digunakan untuk sumber penghasilan.(Wright, 2008)

\section{METODE PENELITIAN}

Artikel ini berdasarkan studi literatur, yang bersumber dari pencarian referensi cetak dan elektronik serta pengalaman penulis selama mengajar mata kuliah audio visual

\section{HASIL DAN PEMBAHASAN}

\section{Kamera Video}

Dalam tahap pengambilan gambar adegan, dapat dilakukan dengan menggunakan kamera video, baik menggunakan kamera video professional maupun menggunakan video kamera sederhana seperti Handycam.

Kemampuan merekam setiap kamera video juga berbeda sesuai dengan kebutuhannya. Contoh kamera professional yang ada tersedia seperti Panasonic DVC62 (Gambar 1) dan Canon XL2 (Gambar 2), kamera ini sudah menggunakan tehnologi 3CCD, yaitu tehnologi yang menggunakan 3 komponen dimana masing masing komponen memancarkan warna cahaya yang berbeda yaitu Red, Green dan Blue. Sensor ini bisa menghasilkan tampilan warna dan gambar yang jauh lebih baik dari teknologi terdahulunya yaitu single CCD, dimana teknologi ini hanya menggunakan satu komponen yang menggabungkan ketiga warna tersebut. Kedua jenis kamera ini masih menggunakan kaset mini $d v$ sebagai media penyimpanannya. 


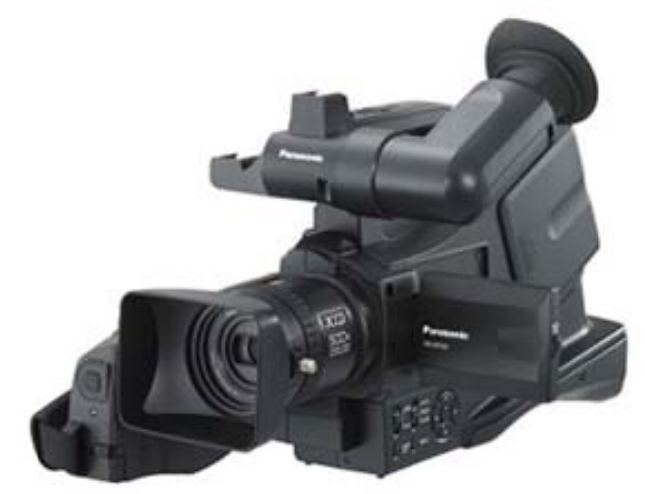

Gambar 1 Panasonic DVC62

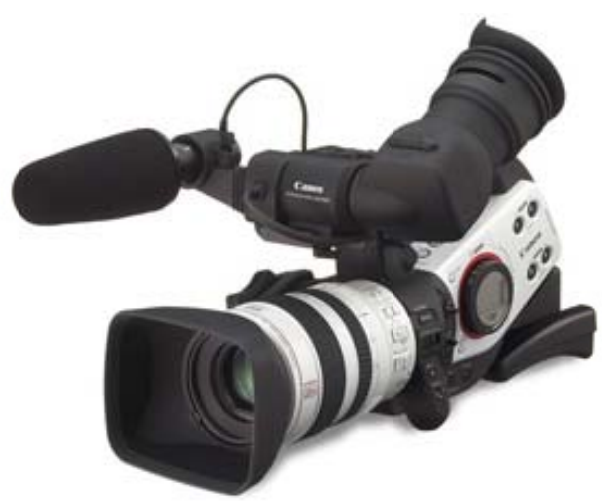

Gambar 2 Canon XL2

Selain kamera professional yang beredar di pasaran, kini kamera video genggam atau yang lebih dikenal dengan handycam sampai dengan Kamera $D S L R$ yang biasa digunakan sebagai alat fotografi, kini bisa digunakan sebagai media perekam yang juga menggunakan tehnologi terbaru, seperti fitur penangkapan gambar video sampai dengan resolusi full HD dengan besar 1920x1080 pixel. Kedua jenis kamera ini sudah menggunakan media penyimpanan $S D$ card dan $C F$ card yang biasa digunakan kamera DSLR pada umumnya. Contohnya Samsung HMX - H100P (Gambar 3) dan Canon DSLR 7D.

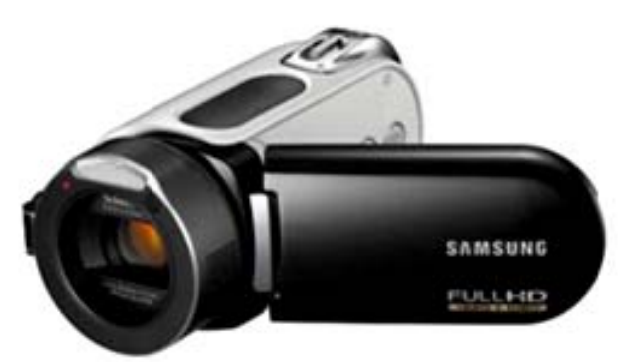

Gambar 3 Samsung HMX-H100P

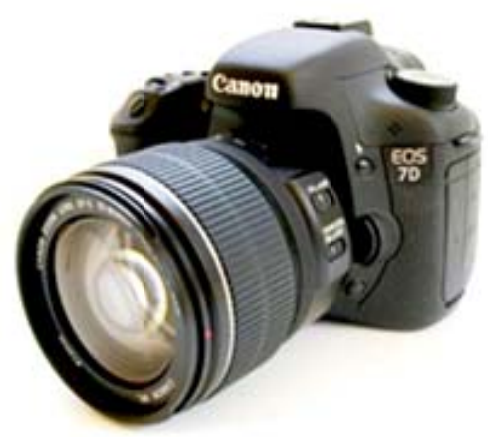

Gambar 4 Canon DSLR 7D 


\section{Capturing dan Editing}

Setelah proses mengambilan gambar menggunakan kamera video,kini dapat dilanjutkan dengan proses mengolah data dari kaset mini $d v$ maupun $S D$ card menjadi sebuah file digital untuk melanjutkan proses editing, yang biasa disebut dengan istilah capturing. Dalam proses capture ini, diperlukan alat bantu berupa VCR (Video Cassette Recorder) untuk memutar kembali video yang terekam dengan menggunakan media mini $d v$ serta media memory card reader untuk membaca media SD card dan CF card yang digunakan untuk penyimpanan hasil shooting.

Banyak sekali produsen yang mengembangkan produk VCR, diantaranya adalah JVC (Gambar 5) dan Sony (Gambar 6).

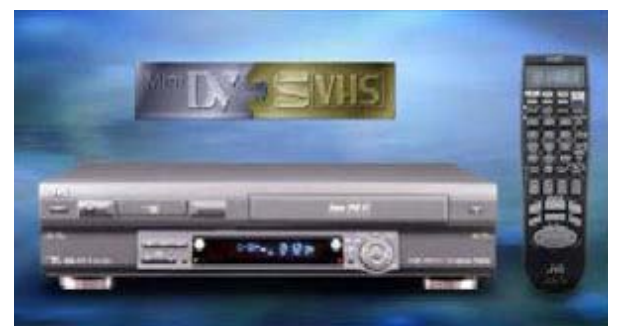

Gambar 5 JVC SR-VS30 PAL

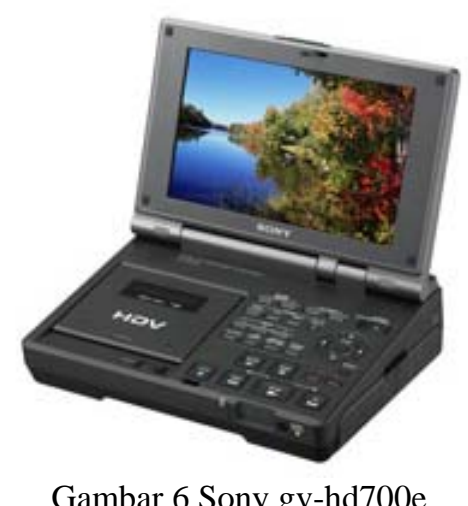

Gambar 6 Sony gv-hd700e

Alat alat tersebut biasanya digunakan untuk memutar ulang setiap adegan yang telah ditangkap menggunakan kamera video guna memilah adegan. Selain peralatan diatas, peralatan lain untuk mendukung tahap ini juga harus memadai, seperti komputer. Komputer dengan spesifikasi yang tinggi mutlak diperlukan, seperti menggunakan prosesor dengan multi core, dengan minimum memori RAM 2 gb, serta kartu grafis yang menunjang, dengan memori minimal 256 mb serta kapasitas Hardisk yang cukup, karena penyimpanan file video ini memerlukan kapasitas penyimpanan yang sangat besar.

Untuk saat ini, mendapatkan komputer dengan spesifikasi seperti ini sudah sangat mudah di jumpai di pasaran. Selain melakukan perakitan komputer sesuai dengan spesifikasi yang di butuhkan, dapat juga ditemui produsen komputer yang menyediakan komputer siap pakai dengan spesifikasi tinggi yang sudah memadai untuk media penyuntingan video.Komputer secara umum di bedakan dengan penggunaan sistem pengoperasian, yaitu dengan berbasis sistem operasi Windows dan Macintosh.Produsen komputer siap pakai yang mengasung sistem operasi window banyak sekali ditemukan di pasaran, seperti Acer, HP, Dell dan masih banyak lagi. Kemudian yang kedua adalah komputer yang menggunakan sistem operasi berbasisMac, produksi Apple Computer (Gambar 7). 


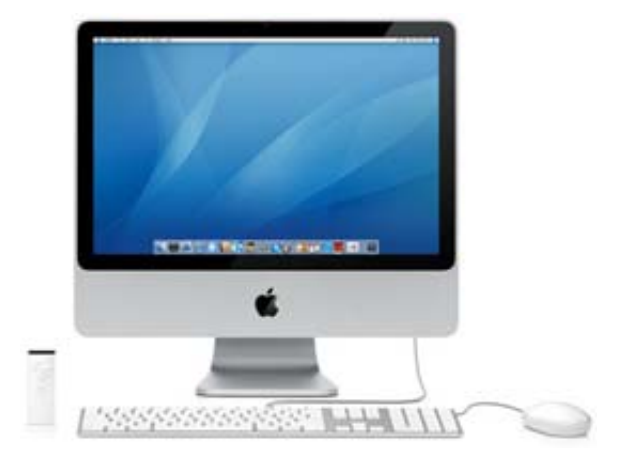

Gambar 7 Apple iMac Berbasis Sistem Operasi Mac

Setelah mengetahui jenis komputer yang dapat dipakai dan VCRyang menunjang, alat penunjang lainnya yang digunakan untuk mentransfer data mini $d v$ menjadi data file adalah kartu firewire 400 dengan sistem tranfer data berkecepatan tinggi, yaitu $400 \mathrm{MB}$ per detiknya. Pada umumnya, kartu ini dijual secara terpisah dan bisa didapat dengan harga yang terjangkau.Namun apabila pada pemilihan mainboard yang sudah cukup baik, port fire wire ini biasanya sudah tersedia.Pada penggunaan media ini, port fire wire ini membutuhkan kabel transfer (Gambar 8) untuk menghubungkan komputer dengan VCR.

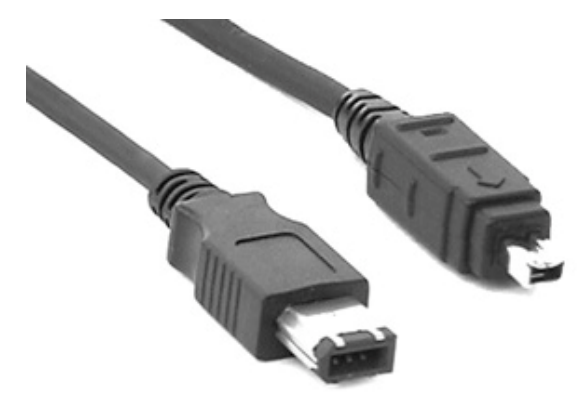

Gambar 8 KabelIEEE 1394 / Firewire400

Setelah perangkat $V C R$ tersambung dengan komputer, proses capturing dapat dilanjutkan dengan pengoperasian software editing. Software yang dapat digunakan untuk proses capturing ini sangat mudah ditemui, diantaranya adalah Sony Vegas dan Adobe Premiere Pro. Adobe Premiere Pro adalah software video editing yang umum dgunakan dalam kebutuhan penyuntingan video.

Berikut ini adalah penjelasan sederhana dalam melakukan proses capturing menggunakan software Adobe Premier pro CS3. Pada tampilan utama (Gambar 9), terdapat berbagai pilihan format video sesuai dengan kebutuhan dan tehnik penggambilan gambar serta jenis kamera yang digunakan, mulai dengan standard definition sampai dengan High Definition.

\section{Standard Definition}

Standard definition adalah ukuran standard televisi yang menggunakan rasio lebar gambar 4:3 dan widescreen dengan rasio 16:9 menggunakan layar lebar yang biasa dikenal dengan sistem PAL dan NTSC. Pada ukuran video DV-PALstandard maupun widescreen menggunakan ukuran gambar yang sama yaitu 720x576 pixel dengan frame rate 25 frame/second (25 gambar per detik). Kualitas gambar ini mempunyai kualitas gambar seperti $d v d$-video. 


\section{High Definition Video}

High definition Video adalah video dengan ukuran gambar yang besar, yang memiliki kualitas gambar yang sangat baik, 2 kali lebih besar dari standard definition, biasa digunakan untuk film layar lebar. Video ini memiliki ukuran gambar yang besar sampai dengan resolusi 1920x1080 pixel yang kerap dengana sebutan "1080" dan resolusi 1280x720 yang dikenal sebagai “720”.Semakin besar resolusi gambar, semakin rapat pixel yang ditampilkan maka semakin baik kualitas sebuah film.

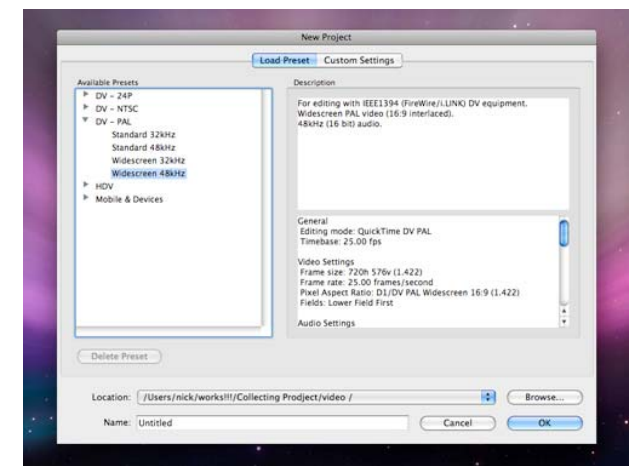

Gambar 9 Pilihan Format Video Pada Premiere Pro cs3

Setelah menentukan jenis ukuran video yang sesuai dengan kebutuhannya, kini dapat dilanjutkan dengan proses capturing. Pada menu file adobe premiere, dapat ditemukan menu capture (Gambar 10) atau bisa dengan menekan tombol F5 pada keyboard

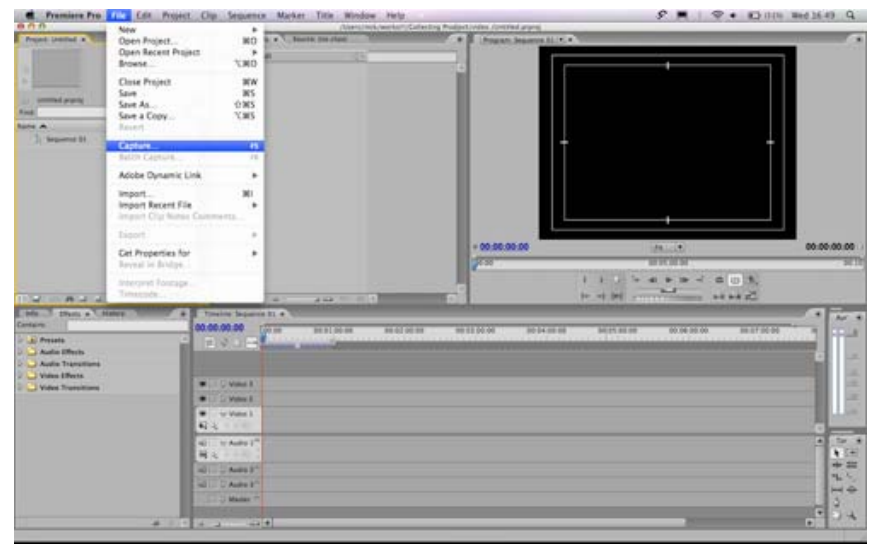

Gambar 10 Menu Capture Pada Adobe Premiere Pro CS3

Dalam menu setting, dapat dilakukan pengaturan format penyimpanan file, lokasi penyimpanan hasil capture, sampai dengan pengaturan alat yang dipakai dalam proses pemindahan data. Dalam menu option pada device control, dapat dilakukan pemilihan alat yang digunakan sebagai media untuk membaca kaset mini $d v$. Setelah proses pengaturan alat dilakukan, dapat dilanjutkan dengan fitur pengendalian untuk melakukan pemilihan adegan per adegan guna untuk memilih adegan yang baik kemudian dilakukan penyimpanan file.

Pada menu logging untuk melakukan proses pemilihan gambar yang akan di olah. Pada proses ini terdapat fitur untuk melakukan pemotongan adegan demi adegan dengan berdasarkan timecode (pencatatan waktu) yang dilakukan pada saat pengambilan gambar. Dengan menekan tombol 
Set In utuk awal pengambilan adegan dan menekan tombol Set Out untuk akhir pengambilan adegan. Kemudian dilanjutkan dengan menekan tombol Log Clip untuk menyimpan.

Dalam proses capturing ini juga dapat dilakukan penyimpanan data secara keseluruhan tanpa melakukan pemotongan adegan, yaitu dengan cara mengaktifkan tombol in/out pada fiturCapture. Namun proses ini memerlukan kapasitas hardisk yang besar untuk penyimpanan file video. Setelah selesai pada proses pemilihan adegan, dapat dilanjutkan dengan melakukan proses Batch Capture yang terdapat pada menu bar $>$ File $>$ Batch Capture atau dengan menekan tombol F6. Pada proses ini, adegan yang sudah terpilih dalam bentuk Log Clipakan diubah menjadi file yang siap di gunakan dalam pengolahan gambar. Setelah semua proses capture dilakukan, file video sudah siap masuk ke tahap editing. Pada tahap ini, dapat dilakukan proses penggabungan file video mengikuti alur cerita yang terkandung dalam naskah. Dalam proses editing ini dapat dilakukan berbagai macam kebutuhan guna untuk memaksimalkan hasil video, antara lain pengaturan warna, memberikan text sampai dengan memberikan effect pada gambar.

Pada tahap akhir setelah semua proses penyuntingan gambar selesai, dapat dilakukan penggabungan semua file video menjadi satu hasil akhir. Tahap ini dapat dilakukan dengan cara memilih fitur Export Movie pada pilihan menu File. Pada proses ini dapat dilakukan pengaturan tipe file akhir untuk hasil yang baik. Pada menu Export>Video terdapat berbagai macam pilihan compressor yang menentukan kualitas akhir sebuah file movie.Pada umumnya compressor dapat dipilih sesuai dengan file video awalpada proses capturing, agar tidak menurunkan kualitas gambar atau dapat memilih hasil yang tebaik tanpa menurunkan kualitas gambar yaitu Animation atau pemilihan None. Tetapi perlu diingat, untuk menyimpan dalam file ini memerlukan ruang penyimpanan pada hardisk yang cukup besar.

\section{Media Penyimpanan}

Pada tahap ini, movie sudah siap untuk di nikmati hasilnya pada layar komputer, tetapi bila ingin menyaksikan menggunakan media DVD Player, file movie yang sudah jadi dapat di transfer menjadi file DVD-Video. Pada tahap ini diperlukan program untuk membuat DVD-Video. Banyak sekali program yang dapat digunakan untuk membuat DVD Video, antara lainUlead Movie Maker, Nero, Toast Titanium dan masih banyak lagi.Pada penggunaan program Toast Titanimum 10 untuk membuat DVD -Video sangat mudah dioperasikan. Pada tampilan Utama (Gambar 11), terdapat beberapa menu pilihan, dan didalamnya terdapat menu pilihanvideo $>D V D$-Video.Pada munu Options dapat dilakukan pengaturan menu dvd dan pemberian nama/ judul videonya

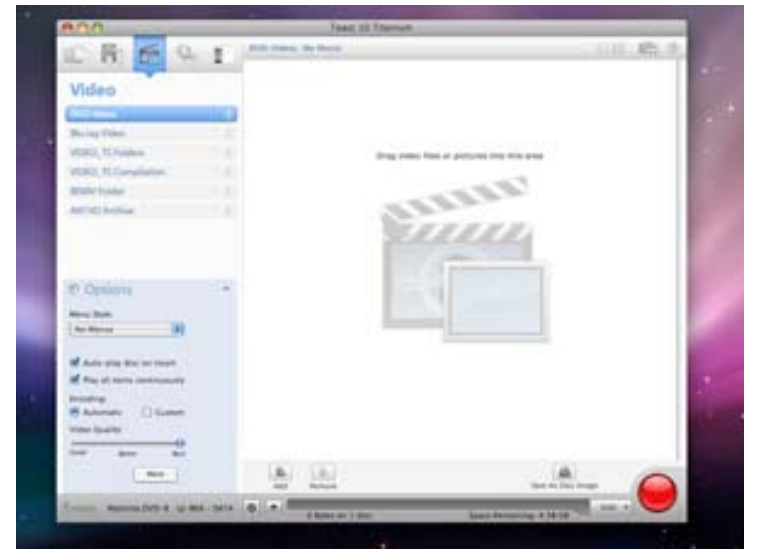

Gambar 11 Tampilan Program Toast Titanium 10 


\section{SIMPULAN}

Dunia editing video sangat menarik sekali untuk di jadikan sebagai hobi sampai dengan sumber penghasilan, maraknya festival film independent juga tidak terlepas dengan sinematografi dan dunia editing. Dengan segala perkembangan zaman serta kemajuan teknologi serta sumber daya manusia yang semakin berkembang dengan kemampuan pengolahan video dengan baik diharapkan dapat memajukan dunia perfileman di Indonesia. Secanggih apapun peralatan digital yang dipakai untuk menangkap gambar dan suara, manusia tetap akan menerima sinyal gambar dan suaradalam bentuk analog. Seperti awan di langit, ombak di lautan dan suara marching band, semua ini dalam pembentukan dari pengalaman yang dilihat oleh manusia.Bagaimanapun juga, manusia tidak menerima frekuensi digital. Karena itu apa yang didengar dan dilihat, manusia akan tetap mengkonversi kembali data digital menjadi format analog. (Weise \& Weynand, 2004)

\section{DAFTAR PUSTAKA}

Weise, M. and Weynand, D. (2004). How Video Works.

Wheeler, Pl. (2007). High Definition Cinematography, second edition, Oxford: Elsevier Inc

Wright, S. (2008). Compositing Visual Effects, Essentials for the Aspiring Artist. Oxford: Elsevier Inc 